IRA-International Journal of Management \& Social Sciences

ISSN 2455-2267; Vol.04, Issue 02 (2016)

Pg. no. 439-446

Institute of Research Advances

http://research-advances.org/index.php/RAJMSS

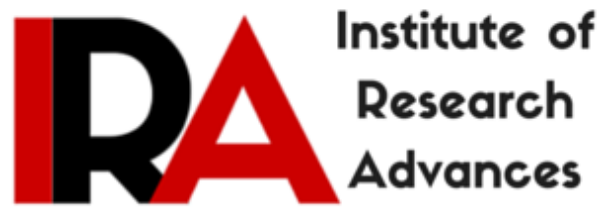

\title{
Importance of Websites in Open and Distance Learning: A Study of Priorities and Expectations of Mass Communication Students from their Institutions' Websites
}

Poonam Gaur

Assistant Professor, Noida International University, Gautam Budh Nagar, UP, India.

Type of Review: Peer Reviewed.

DOI: http://dx.doi.org/10.21013/jmss.v4.n2.p13

\section{How to cite this paper:}

Gaur, P. (2016). Importance of Websites in Open and Distance Learning: A Study of Priorities and Expectations of Mass Communication Students from their Institutions' Websites. IRA-International Journal of Management \& Social Sciences (ISSN 24552267), 4(2), 439-446. doi:http://dx.doi.org/10.21013/jmss.v4.n2.p13

(C) Institute of Research Advances

(c) BY-NC

This work is licensed under a Creative Commons Attribution-Non Commercial 4.0 International License subject to proper citation to the publication source of the work.

Disclaimer: The scholarly papers as reviewed and published by the Institute of Research Advances (IRA) are the views and opinions of their respective authors and are not the views or opinions of the IRA. The IRA disclaims of any harm or loss caused due to the published content to any party. 


\section{ABSTRACT}

Open and Distance Learning (ODL) has very crucial role in our higher education. According to Distance Education Bureau, UGC; approx. 23.50\% of the total higher education enrolment comes from distance education but this mode has been facing few major challenges since the time of its inception. 'Distance' is the biggest challenge for ODL. Distance educators have been trying to overcome this issue with the help of technology. ICT is the most appropriate solution. The interactive nature of this technology can minimize the impact of 'distance'. Website is one of the most important tool of ICT. This study talks about the priorities and expectations of ODL mass communication students from the Websites of their Institutions. The paper highlights the different characteristics and features of an effective website from the ODL learners' point of view.

Keywords : website, effectiveness, mass communication education, open and distance learning

\section{INTRODUCTION}

Information and Communication Technology (ICT) is playing very important role in every field of life. Now, it is difficult to imagine the life without ICT. We are using ICT effectively in governance, commerce, education and even religion also. Despite the existence of digital divide, ICT based services have completely revolutionized these fields and made these services smoother, easier and transparent. Open and Distance Learning (ODL) is also not an exception. ICT has changed this sector too. Immediacy and interactivity, the major characteristics of ICT, have huge potential to provide the effective solutions of the issues faced by distance education.

'Distance' is the biggest challenge for ODL. Distance between students and teacher, distance between student and student and distance between institution and student make this mode more challenging. Distance educators have been trying to overcome this issue with the help of technology and ICT is the most appropriate solution. We all know that Open and distance education is our need. It serves many purposes. It is very difficult for a developing country like India with a huge population to fulfil the need of higher education by the conventional face to face teaching mode. Budgetary constraints; social, economic and geographical diversity of the population; and the changing need of professional and technical sectors where continuous updating of knowledge is required; create such a situation where open and distance learning is must. So now the focus is to make this mode more and more effective and ICT is the best way out.

Website: 'Website' is one of the most common and popular term in our ICT based life. Websites provide platform for various ICT based services and this feature clearly declares their importance. In a country of 462 million internet users (source: IAMAI), websites are very crucial for any organization. According to ENCYCLOPÆDIA BRITANNICA, "Web site, Collection of files and related resources accessible through the World Wide Web and organized under a particular domain name. A Web site's usual starting point or opening page, called a home page, usually functions as a table of contents or index, with links to other sections of the site." Website is the virtual face of any organization including educational institutions and quality of website plays pivotal role in developing the image of that particular organization. Wells, Valacich \& Hess (2011) found that the quality of website helped to create perception about the quality of product or services provided by any organization.

In the context of academic institutions websites are used for various purposes like: i) To provide information about the institution ii) To reach and communicate with prospective students. iii) To communicate with existing students. iii) To provide various administrative services to prospective and existing students. iv) To provide academic content to the students.

ODL Students and Website: ODL students' requirements are different from regular face to face students. They face 'distance' generated problems. An effective website can provide solutions to many of 
those issues. Few challenges faced by ODL students and importance of effective websites in providing solutions are following:

i) Distance between student and institution: Distance students do not visit their institutions regularly. So they are more dependent on institution's website for Information. Administrative services through websites (online mode) can provide a lot of help to these ODL leaners and various queries can be answered through online interactivity.

ii) Distance between student and teacher: Unlike face to face conventional mode, distance students do not meet their teachers or instructors regularly. In this case, online interactivity with teachers/counsellors are quite useful for ODL learners. Online academic content (text, audio, video, multimedia etc.) can also be provided.

iii) Distance between student and student: Interaction with peer group is an important factor in learning process. Distance students lack this facility but online discussion platforms can solve this problem too to a certain extent. .

Effective websites can reduce the impacts of the factor, 'Distance'. In comparison with face to face regular students, ODL learners' are more in need of effective websites of their respective institutions.

Effectiveness of website: Effectiveness can be defined in different ways but in the context of this study the term 'Effectiveness' was taken from the ISO quality model for 'Quality in use' for software products.

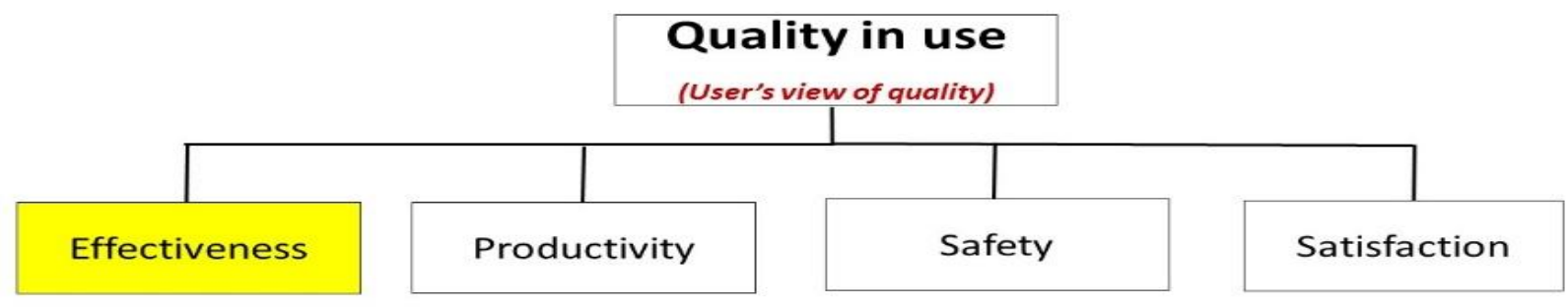

(Quality model for quality in use : ISO/IEC FDIS 9126-1:2000(E), Standards for Information technology - Software product quality )

ISO 9126 (2000) defines effectiveness, "The capability of the software product to enable users to achieve specified goals with accuracy and completeness in a specified context of use." Here users are ODL learners/students and open and distance learning is the specified context of use. It means, in this context, effectiveness of a website is its capability to enable distance learners to achieve their goals with accuracy and completeness in distance learning process.

\section{LITERATURE REVIEW}

In this digital age, we can say without fail that websites are vital for any organization. The importance of websites attracted many scholars to undertake various studies on different aspects of websites. A lot of studies have been done on different aspects of websites specially in two disciplines, management and computer sciences. Different studies highlighted the importance of effective websites in different sectors including higher education and even distance education also.

According to Zhang and Dran (2002), "website functions as a 'window' through which users have their initial interaction with the organization." Wells, Valacich \& Hess (2011) found that the quality 
of website influenced the consumers' perceptions of product quality and finally purchase intention. They conducted this research in the context of e-commerce. It means the website quality indicates the quality of product or services in the minds of prospective buyers or users. The ODL and e-commerce both share a common thing that is higher information asymmetries due to the physical distance between service provider and user.

Need for quality website for schools, universities and other educational institutions is constantly increasing, as online technologies become a bigger part of the educational process as well as decision support for prospective students in selecting their place of study. The website also reflects the professional image of the institution (N. Elangovan, 2013).

In the era of commercialization, educational institutions are also behaving like any other business organization. The economic model of these educational institutions and cut throat competition among them force them to adopt high class marketing practices. Effective website is one of important tools of marketing. Menon and Moitra (2014) found that private universities were far ahead in realizing the need of an effective websites than government state universities in Maharashtra.

According to Hidayanto, Rofalina \& Handayani (2015) "First, the quality of university website can serve as a signal of university education's quality. Secondly, the perceived quality of university education, which is based on signaling theory, eventually influences the enrollment intention of prospective students to the university. Considering our results, universities should pay more attention to their official website in order to gain attention from prospective students."

Schimmel et al. (2010) reached to the conclusion that university's website had become a very important tool for the first step of selection of the institution. Prospective students are heavily dependent upon the websites for information gathering. Information about programmes, courses offering, accreditation and location should be placed prominently on home page.

While evaluating the different aspects of websites, few scholars conducted studies in the specific context of distance education also. Providing detailed models of web enabled education and shared databases for Open and Distance Learning, Sharma (2010) highlighted the importance of websites for ODL institutions. She covered both administrative and academic activities undertaken by ODL system. She emphasized on the fast changing capacity of websites which could be useful in both academic content delivery and administrative activities.

Evaluating effectiveness of the ODL institutions' websites located in West Bengal Panigrahi, Das \& Basu (2011) found that design and service related attributes needed to be increased in the websites of ODL institutions. They emphasized on the incorporation of more e-learning tools to reduce the impact of 'distance.' As per their findings, better ICT enabled distance learning can solve the issue of Gross Enrolment Ratio of the states like West Bengal.

\section{OBJECTIVES}

The objectives of this study are following:

i) To find out the priorities and expectations of ODL mass Communication Students from the Websites of their respective Institutions.

ii) To prepare a checklist of different characteristics and features for evaluation of the websites of ODL institutions from student's point of view. 


\section{RESEARCH METHODOLOGY}

According to Office of Communications, Princeton University, (2008) "The best websites are created with a keen understanding of visitors' interests, needs and expectations." So the user should always be in the focus.

Both qualitative and quantitative tools were used for this study. Focus group discussion and survey were used to collect the data. Three focus group discussions and a small survey were conducted to find out the priorities and expectations of ODL mass Communication Students from the Websites of their respective Institutions.

Two types of ODL learners/students were invited for focus group discussions:

i) Students/learners pursuing mass communication programmes through ODL from any Indian institution.

ii) Persons completed mass communication programmes through ODL from any Indian institution but not before 2011.

Total 32 ODL learners were involved in these three focus group discussions and the same group of students/learners was used as the respondents of survey questionnaire.

\section{FINDINGS}

The major expectation of ODL mass Communication students from their institution's websites are following:

1) Information: The website should have all the required and updated information in detail.

2) Services: The website should have the links for various online administrative services like: online admission, online examination forms, etc.

3) Academic Content: Keeping the nature of open and distance learning in view, academic content should be available on websites. For example: study material, video lectures, etc.

4) Major interactive tools: Though interactivity is a broader term, the students want to have few major interactive tools on their institutions' websites. Ex - Chatting tools, complain or query boxes, etc.

5) User-friendliness: Students have few expectations related to user-friendliness of websites. They asked for few features like: website should be mobile friendly, multi-language etc.

These expectations may be labeled as the characteristics of an effective website from ODL students' point of view. The following table shows the priority given to these 5 characteristics by the ODL mass communication students.

Table: 1 (Priorities of ODL students)

\begin{tabular}{|l|l|l|l|l|l|l|}
\hline S.No. & $\begin{array}{l}\text { Characteristics of } \\
\text { Website }\end{array}$ & $1^{\text {st }}$ Priority & $2^{\text {nd }}$ Priority & $3^{\text {rd }}$ Priority & $4^{\text {th }}$ Priority & $5^{\text {th }}$ Priority \\
\hline 1 & Information & $\mathbf{2 5}$ & 01 & 02 & 02 & 02 \\
\hline 2 & Services & 04 & $\mathbf{2 0}$ & 08 & 00 & 00 \\
\hline 3 & Academic Content & 02 & 09 & $\mathbf{2 0}$ & 00 & 01 \\
\hline 4 & Interactive Tools & 00 & 02 & 02 & $\mathbf{2 0}$ & 08 \\
\hline 5 & User-friendliness & 01 & 00 & 00 & 10 & $\mathbf{2 1}$ \\
\hline & Total & 32 & 32 & 32 & 32 & 32 \\
\hline
\end{tabular}


The examination of table: 1 shows that the first and most important expectation of ODL students form their institution's website is 'information'. Since unlike regular face to face students, they don't visit their institutions regularly so they need detail and updated information from institution's website. Second priority is given to 'services', then third to 'academic content' and 'interactive tools' and 'userfriendliness' stand on $4^{\text {th }}$ and $5^{\text {th }}$ position respectively.

After finalizing the characteristics and their importance or priority wise ranking, different features of different characteristics were also discussed and found out. These features can be measured both quantitatively and qualitatively. Table: 1.1 shows the different features of all 5 identified expectations of ODL students form their institution's websites:

Table: 1.1 (Features of characteristics)

\begin{tabular}{|c|c|c|c|c|c|}
\hline & Information & Services & $\begin{array}{l}\text { Academic } \\
\text { Content }\end{array}$ & Interactivity & $\begin{array}{l}\text { User- } \\
\text { friendliness }\end{array}$ \\
\hline $\mathrm{i}$ & $\begin{array}{l}\text { Information } \quad \text { about } \\
\text { Institution }\end{array}$ & $\begin{array}{l}\text { Online } \\
\text { admission }\end{array}$ & $\begin{array}{l}\text { SLMs } \\
\text { available on } \\
\text { website }\end{array}$ & $\begin{array}{l}\text { Queries/feedbac } \\
\text { k/grievance box }\end{array}$ & $\begin{array}{l}\text { Mobile } \\
\text { friendly } \\
\text { website }\end{array}$ \\
\hline ii & $\begin{array}{l}\text { Administrative } \\
\text { information: Admission, } \\
\text { Exam etc. }\end{array}$ & $\begin{array}{l}\text { Online } \\
\text { Examination } \\
\text { form } \\
\text { submission }\end{array}$ & $\begin{array}{l}\text { Multimedia } \\
\text { Content or } \\
\text { link }\end{array}$ & text Chat facility & $\begin{array}{l}\text { Multi } \\
\text { Language }\end{array}$ \\
\hline iii & Prospectus / Brochure & $\begin{array}{l}\text { Online admit } \\
\text { card / hall-ticket }\end{array}$ & $\begin{array}{l}\text { Own } \\
\text { repository }\end{array}$ & $\begin{array}{l}\text { Audio Chat } \\
\text { facility }\end{array}$ & Search option \\
\hline iv & $\begin{array}{l}\text { Curriculum / Programme } \\
\text { structure }\end{array}$ & Online result & $\begin{array}{l}\text { Link to other } \\
\text { e-repositories }\end{array}$ & $\begin{array}{l}\text { video chat } \\
\text { facility }\end{array}$ & $\begin{array}{l}\text { Links of SNS } \\
\text { on website }\end{array}$ \\
\hline $\mathrm{v}$ & Old question papers & $\begin{array}{l}\text { Online } \\
\text { Assignments }\end{array}$ & E-library & Feedback survey & \\
\hline vi & $\begin{array}{l}\text { General brief contact } \\
\text { information of the } \\
\text { institution }\end{array}$ & $\begin{array}{l}\text { Online } \\
\text { registration } \\
\text { facility for } \\
\text { placement }\end{array}$ & $\begin{array}{l}\text { Audio } \\
\text { webcast } \\
\text { (Internet } \\
\text { radio) }\end{array}$ & & \\
\hline vii & $\begin{array}{ll}\text { Name \& } & \text { Contact } \\
\text { information of } & \text { concern } \\
\text { persons in detail } & \\
\end{array}$ & $\begin{array}{l}\text { Login link for } \\
\text { students (LMS) }\end{array}$ & $\begin{array}{l}\text { Video } \\
\text { webcast } \\
\text { (Internet TV) } \\
\end{array}$ & & \\
\hline $\begin{array}{l}\text { vii } \\
\text { i }\end{array}$ & Placement Information & \begin{tabular}{lr}
\multicolumn{2}{l}{ Availability of } \\
other required \\
forms r for \\
learners
\end{tabular} & & & \\
\hline ix & Alumni & & & & \\
\hline $\mathrm{x}$ & FAQs & & & & \\
\hline
\end{tabular}

The number of features for each characteristic is different so their weightage is also different. The characteristics scored higher priority ranking from ODL learners/students have more number of features and subsequently higher weightage. The ODL students gave first priority to 'information' so number of features for this characteristic is also highest (10). Other characteristics, services has 8 features, academic content has 7, interactive tools has 5 and user-friendliness has minimum 4. Chart: 1 shows the weightage of each characteristics : 


\section{Chart: 1}

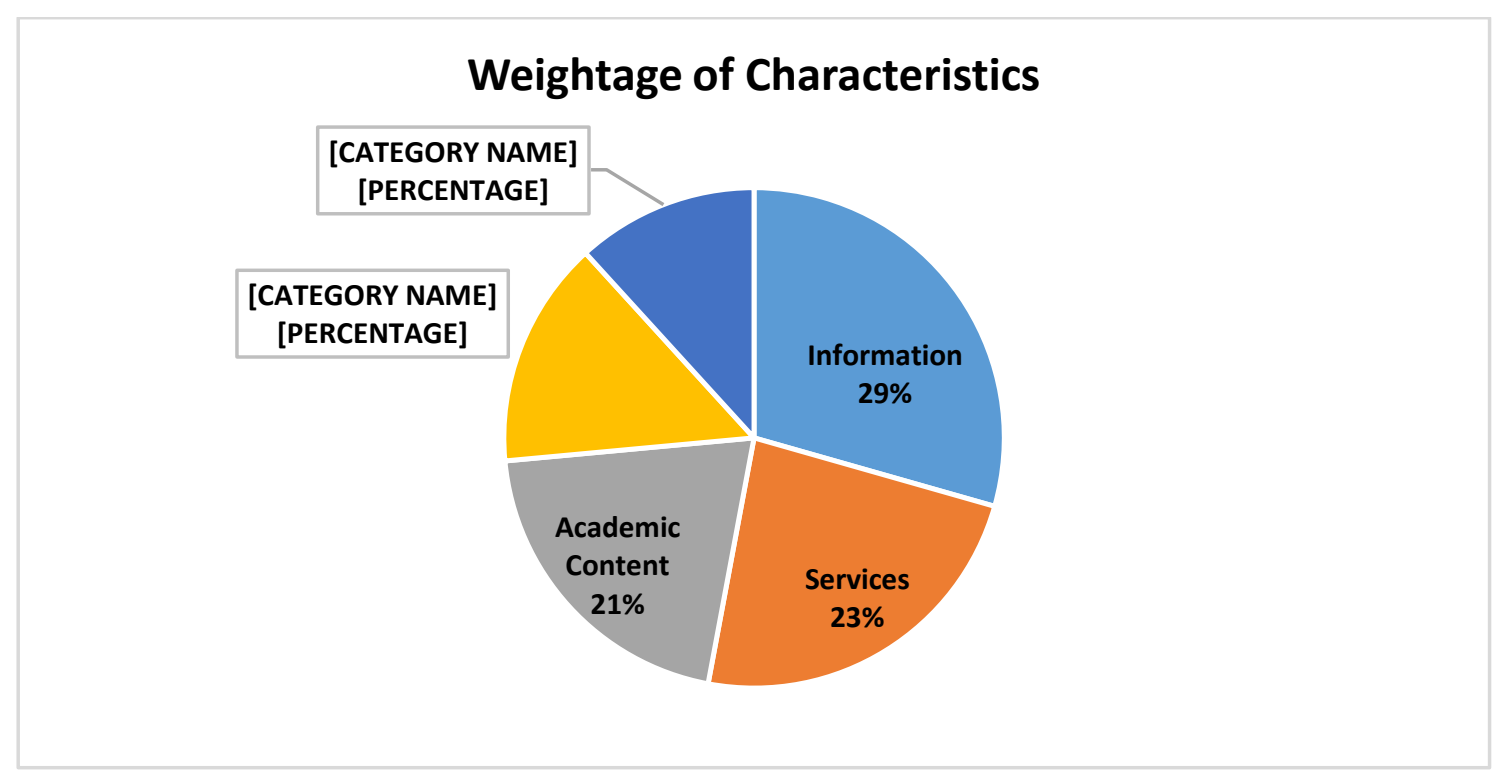

\section{CONCLUSIONS}

The open and distance learning (ODL) students are in more need of effective websites than their regular face to face counterparts. Their needs are different also. 'Distance' is the biggest challenge for the students of this mode but effective websites can reduce its impact. Distance learners consider their institutions' websites as an effective tool of ICT to ease their problems. They expect information, services, academic content, interactive tools and user-friendliness from the websites of their institutions. If we see their priorities, information is most important for them. They want online administrative services and availability of academic content on their institutions' websites. They expect few interactive tools and few features related to user-friendliness in these websites.

\section{REFERENCES}

Elangovan, N. (2013). Evaluating Perceived Quality of B-School Websites. IOSR Journal of Business and Management, 12(1), 92-102. doi: 10.9790/487X-12192102

Hidayanto, A.N., Rofalina, F., \& Handayani, P.W. (2015). Influence of Perceived Quality of University official Website to Perceived Quality of University Education and Enrollment Intention. The Evolution of the Internet in the Business Sector: Web 1.0 to Web 3.0, 278-305. doi: 10.4018/9781-4666-7262-8.ch013

International Organization for Standardization. (2000). Information technology - Software product quality. Retrieved from https://www.cse.unsw.edu.au/ cs3710/PMmaterials/Resources/9126$1 \% 20$ Standard.pdf

Menon, S.A., \& Moitra, R. (2014). A comparative study of state and private university websites in Maharashtra. IOSR Journal Of Humanities And Social Science, 19(12), 18-21. Retrieved from http://iosrjournals.org/iosr-jhss/papers/Vol19-issue12/Version-2/D0191221821.pdf 
Office of Communications, Princeton University. (2008). Guide to Creating Website Information Architecture and Content (Version 2.2). Retrieved from https://www.princeton.edu/communications/services/docs/IAguide2.pdf

Panigrahi, G., Das, A., \& Basu, K. (2011). A study to increase effectiveness of distance learning websites in India with special reference to the state West Bengal to increase the present GER of higher education through incorporation of E-learning facility in a better way. Procedia Social and Behavioral Sciences 15, 1535-1539. doi:10.1016/j.sbspro.2011.03.326

Schimmel, K., Motley, D., Racic, S., Marco, G., and Eschenfelder, M. (2010). The importance of university web pages in selecting a higher education institution. Research in Higher Education Journal, 9(1):1-16. Retrieved from http://www.aabri.com/manuscripts/10560.pdf

Sharma, M. (2010). Website: a Major ICT Tool in ODL for Providing Quick Information and Learning Environment to Masses. OAsis, COL's Publications Repository. Retrieved from http://oasis.col.org/handle/11599/2058

Web-site. (n.d.). In ENCYCLOPAEDIA BRITANNICA. Retrieved from https://www.britannica.com/topic/Web-site

Wells et al. 2011. What Signal Are You Sending? How Website Quality Influences Perceptions of Product Quality and Purchase Intentions.MIS Quarterly, Vol. 35, No. 2, pp 373-396.

Wells, J.D., Valacich, J.S. \& Hess, T.J. (2011).What Signal Are You Sending? How Website Quality Influences Perceptions of Product Quality and Purchase Intentions. MIS Quarterly, 35 (2), 373396.

Zhang, P. \& Von Dran, G.M. (2002). User Expectations and Rankings of Quality Factors in Different Website Domains. International Journal of Electronic Commerce, 6 (2), 9-33. Retrieved from http://melody.syr.edu/pzhang/publications/IJEC_01_Zhang_vonDran.pdf 